\title{
The digestion of fresh perennial ryegrass fertilized at 2 levels of nitrogen in lactating dairy cows
}

\author{
JL Peyraud, L Astigarraga, P Faverdin
}

INRA, station de recherches sur la Vache laitière, 35590 Saint-Gilles, France

The digestion of protein in intensively fertilized grasses is characterized by high losses of nitrogen $(\mathrm{N})$ in the urine. This experiment aimed at studying the effect of lowering $\mathrm{N}$ fertilization on $\mathrm{N}$ metabolism in the dairy cow.

The effect of 2 levels of $\mathrm{N}$ fertilization $(0$ or 80 $\mathrm{Kg} \mathrm{N} / \mathrm{ha}$ before and after the first cut in spring 1991) of fresh perennial ryegrass on digestion was tested with a second cut $(30$-d-old) in a cross-over design on 4 fistulated dairy cows (20 $\mathrm{kg}$ milk). Grass was given ad libitum in 3 meals per day. The flow of duodenal digesta was calculated from $P E G$ and $Y b$ recovered in faeces and their respective concentration in digesta. Feeding behaviour was also recorded.

The absence of $\mathbf{N}$ fertilizer resulted in a reduction in $\mathrm{N}$ content of grass (17.4 vs 24.2 $\mathrm{g} / \mathrm{kg} \mathrm{DM}$ ) and $\mathrm{N}$ intake (NI) (table I) whereas organic matter (OM) intake was not affected (14 kg/d). OM and NDF digestibilities were reduced $(0.79$ vs 0.81 and 0.72 vs 0.78 , respectively for $\mathrm{OM}$ and NDF, $P<$ $0.05)$. Due to a higher DM content in unfertilized grass (197 vs $145 \mathrm{~g} / \mathrm{kg}$ ) time spent eating was reduced (495 vs $607 \mathrm{~min} / \mathrm{d}$ ). The non-ammonia nitrogen flow into the duodenum (NAN) expressed in $\mathrm{g} / \mathrm{d}$ or as a fraction of digestible OM intake $(32.5 \mathrm{~g} / \mathrm{kg}$ DOMI), was similar in the 2 treatments $(P>0.1)$. NAN was equal to $\mathrm{NI}$ in the fertilized grass but exceeded NI by $95 \mathrm{~g} / \mathrm{d}$ in the unfertilized grass. This net recycling matched the quantities of $\mathrm{N}$ excreted in urine (NU) which were indeed reduced by $95 \mathrm{~g} / \mathrm{d}$ (in fact $86 \mathrm{~g} / \mathrm{d}$ urea-N) with the unfertilized grass and could be related to the lower rumen concentration of ammonia $\left(\mathrm{NH}_{3}\right)$. Reduced $\mathrm{N}$ fertilization led both to a slight decrease in feed $\mathrm{N}$ degradability estimated in sacco (0.74 vs 0.77 ) and in the absolute amount of feed $\mathrm{N}$ escaping the rumen degradation - from 96 to $76 \mathrm{~g} / \mathrm{d}$ if predicted from the in sacco degradability (Vérité and Peyraud, 1989). The efficiency of microbial synthesis was calculated to be $25 \mathrm{~g} \mathrm{~N} / \mathrm{kg}$ DOMI and was unlikely to be modified according to the treatment.

In conclusion, these results suggest that reduced $\mathrm{N}$ fertilization greatly affects $\mathrm{N}$ metabolism in the dairy cow, resulting in lower $\mathrm{N}$ excretion in urine.

Vérité R, Peyraud JL (1989) Ruminant Nutrition (Jarrige R, ed) John Libbey and Co, London, 33-47

Table I. Effect of $\mathrm{N}$ fertilization of $\mathrm{N}$ metabolism in dairy cows.

\begin{tabular}{rcrrr}
\hline Fertilization & $\begin{array}{c}N / \\
(g / d)\end{array}$ & $\begin{array}{c}N A N \\
(g / d)\end{array}$ & $\begin{array}{c}N U \\
(g / d)\end{array}$ & $\begin{array}{c}N_{3} \\
(m g / l)\end{array}$ \\
\hline 0 & $263^{\mathrm{a}}$ & 358 & $69^{\mathrm{a}}$ & $15^{\mathrm{a}}$ \\
80 & $367^{\mathrm{b}}$ & 367 & $164^{\mathrm{b}}$ & $99^{\mathrm{b}}$ \\
rsd & $22^{\mathrm{n}}$ & 4 & 5 & 19 \\
\hline
\end{tabular}

a,b: means with different superscripts in the same column are significantly different $(P<0.05)$; rsd: from the model: $Y_{i j k}=$ mean $+(\text { fertilization })_{i}+(\text { period })_{j}+(\text { cow })_{k}$ + eijk. 